\title{
Neurology
}

\author{
A Randomized Trial of High-Dose Vitamin D2 in \\ Relapsing-remitting Multiple Sclerosis \\ Helmut H. Leitner, L. Grimaldi, F. Barkhof, et al. \\ Neurology 2012;78;840-841 \\ DOI 10.1212/01.wnl.0000413180.13413.ce
}

This information is current as of March 12, 2012

The online version of this article, along with updated information and services, is located on the World Wide Web at:

http://www.neurology.org/content/78/11/840.2.full.html

Neurology ${ }^{\circledR}$ is the official journal of the American Academy of Neurology. Published continuously since 1951, it is now a weekly with 48 issues per year. Copyright Copyright (C 2012 by AAN

Enterprises, Inc.. All rights reserved. Print ISSN: 0028-3878. Online ISSN: 1526-632X.

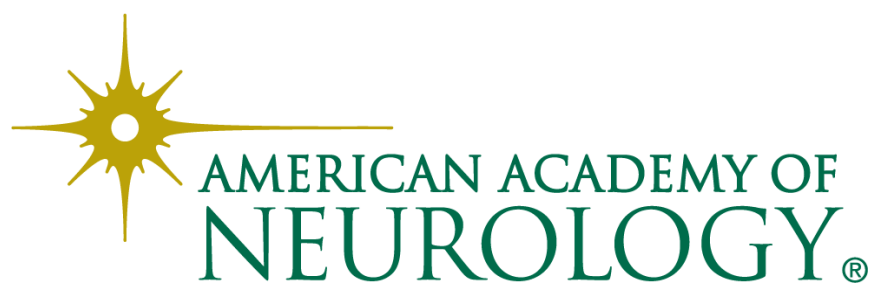




\section{A Randomized Trial of High-Dose Vitamin D2 in Relapsing-remitting Multiple}

Sclerosis

Helmut H. Leitner, L. Grimaldi, F. Barkhof, et al.

Neurology 2012;78;840-841

DOI 10.1212/01.wnl.0000413180.13413.ce

This information is current as of March 12, 2012

\section{Updated Information \&} Services

References

Permissions \& Licensing

Reprints including high resolution figures, can be found at:

http://www.neurology.org/content/78/11/840.2.full.html

This article cites 6 articles, 4 of which you can access for free at: http://www.neurology.org/content/78/11/840.2.full.html\#\#ref-list $-1$

Information about reproducing this article in parts (figures,tables) or in its entirety can be found online at:

http://www.neurology.org/misc/about.xhtml\#permissions

Information about ordering reprints can be found online: http://www.neurology.org/misc/addir.xhtml\#reprintsus

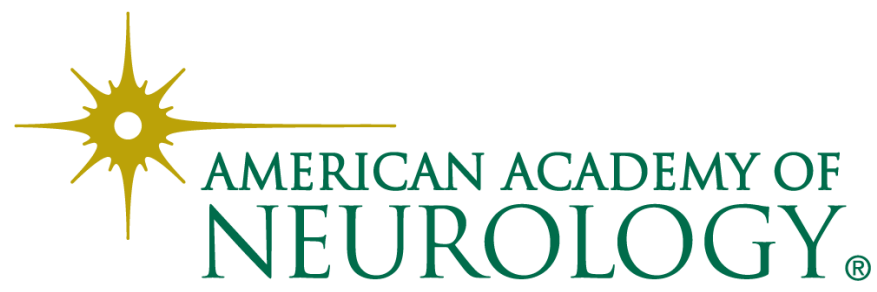




\section{Write Click: Editor's Choice}

Editors' Note: Dr. Santulli, citing the findings of Dr. Mishra et al. that neither diabetes nor prior stroke affected thrombolysis outcomes, calls for the reevaluation of thrombolysis criteria and the adoption of a clinical score, similar to that used in acute coronary syndrome, to stratify risk. There were 2 WriteClick submissions in reference to the recent article by Dr. Stein et al. comparing high-dose and low-dose vitamin D2 supplementation in relapsing-remitting multiple sclerosis. Dr. Leitner calls attention to the incongruity of epidemiologic trends in MS vs another vitamin D-related illness, rickets, as further reason not to supplement patients with MS without proven vitamin D deficiency at this time. Dr. Grimaldi et al. argue that the study was underpowered and potentially biased. Their own phase II study of high-dose vitamin D3 supplementation is under way.

Megan Alcauskas, MD, and Robert C. Griggs, MD

\section{THROMBOLYSIS OUTCOMES IN ACUTE ISCHEMIC STROKE PATIENTS WITH PRIOR STROKE AND DIABETES MELLITUS}

Gaetano Santulli, New York: Mishra et al. ${ }^{1}$ examined the influence of diabetes mellitus and prior stroke on the outcomes of patients who received thrombolysis vs nonthrombolyzed controls. They found no interaction on outcome between diabetes and prior stroke with thrombolysis treatment.

These results conflict with the European Medicines Evaluation Agency's justification for restricting the use of IV alteplase. As Dr. Demaerschalk mentioned in the accompanying editorial, ${ }^{2}$ recent studies ${ }^{1,3,4}$ have suggested that thrombolysis can be safely used in several groups of patients who do not qualify for treatment due to strict application of exclusion criteria.

In addition, most of the commonly cited thrombolytic exclusion criteria are just consensus-based, not evidence-based. ${ }^{2,3}$ It is time to reevaluate the criteria for thrombolysis, adopting a clinical score to stratify the risk, similar to those used in acute coronary syndrome. 5 A good risk assessment tool will be able to identify a gradient of mortality risk by using variables that capture the majority of prognostic information to better evaluate the risk/benefit ratio for each patient.

Copyright (C) 2012 by AAN Enterprises, Inc.
1. Mishra NK, Ahmed N, Davalos A, et al. Thrombolysis outcomes in acute ischemic stroke patients with prior stroke and diabetes mellitus. Neurology 2011;77:1866-1872.

2. Demaerschalk BM. Challenging the validity of imposing contraindications to thrombolysis for acute ischemic stroke. Neurology 2011;77:1862-1863.

3. Tong D. Are all IV thrombolysis exclusion criteria necessary? Being SMART about evidence-based medicine. Neurology 2011;76:1780-1781.

4. Rubiera M, Ribo M, Santamarina E, et al. Is it time to reassess the SITS-MOST criteria for thrombolysis? A comparison of patients with and without SITS-MOST exclusion criteria. Stroke 2009; 40:2568-2571.

5. Morrow DA, Antman EM, Charlesworth A, et al. TIMI risk score for ST-elevation myocardial infarction: a convenient, bedside, clinical score for risk assessment at presentation: an intravenous nPA for treatment of infarcting myocardium early II trial substudy. Circulation 2000;102:2031-2037.

\section{A RANDOMIZED TRIAL OF HIGH-DOSE VITAMIN D2 IN RELAPSING-REMITTING MULTIPLE SCLEROSIS}

Helmut H. Leitner, Vienna: Stein et al. ${ }^{1}$ compared high- vs low-dose vitamin D2 treatment in MS without benefit in the high-dose treatment group. Sunlight exposure and reduced vitamin D3 levels independently contribute to MS risk. The effect of sunlight exposure is supported by decreased signs of actinic skin damage found in MS patients compared to controls. ${ }^{2}$ It is difficult to determine which of these 2 environmental factors is of primary importance as higher levels of sunlight exposure will enhance vitamin D levels.

The incidence of vitamin D-related rickets disease decreased in the United States and Europe during the last century following the discovery that vitamin $\mathrm{D}$ possessed antirachitic properties, whereas the incidence of MS seemed to increase in the same population. In the United States, most of the patients with rickets are African American, whereas the majority of patients with MS are of European ancestry. ${ }^{3}$ It seems improbable that the same environmental factor should be centrally involved in the etiology of both diseases, which differ clinically and occur in different populations living in the same geographic area.

These findings together with those of Stein et al. do not provide a reason for vitamin D supplementa- 
tion in MS aside from correcting a proven vitamin D deficiency. Other factors associated with increased sunlight exposure may more effectively prevent MS.

L. Grimaldi, Cefalù, Italy; F. Barkhof, Amsterdam; M. Beelke, Gauting-Unterbrunn, Germany; J. Burton, Calgary, Canada; T. Holmoy, Oslo; R. Hupperts, Sittard, the Netherlands; J. Killestein, Amsterdam; P. Rieckmann, Wurzburg, Germany; M. Schluep, Lausanne, Switzerland; J. Smolders, Amsterdam; on behalf of the SOLAR study group: The conclusion of Stein et al. ${ }^{1}$ that high-dose ineffective vs low-dose vitamin D2 supplementation in relapsing-remitting MS (RRMS) is not supported by data enabling level 1 evidence.

Randomization to interferon- $\beta$, glatiramer acetate, or no treatment results in very small treatment groups. Such MRI-based randomized placebocontrolled trials would need at least 85 patients per arm to reach statistical significance, assuming 50\% treatment difference ${ }^{4}$ and, since vitamin D effects may appear after 12-24 weeks, an MRI follow-up period of at least 9 -not 6 - months.

In figure 2 , only $4 / 11$ subjects in the higher dose group exhibited $25(\mathrm{OH}) \mathrm{D}$ levels within the $130-$ $175 \mathrm{nmol} / \mathrm{L}$ target range. ${ }^{1}$ Since dosages must have been adjusted continuously throughout the trial, likely fluctuations in serum $25(\mathrm{OH}) \mathrm{D}$ prevent firm conclusions. ${ }^{5}$

During the study, MKTVIF75HV (vitamin D2) was replaced by vitamin D3. As vitamin D2 and D3 are not equivalent, ${ }^{5}$ these results cannot be extended to all "vitamin D" subtypes.

To address these issues, an appropriately powered, randomized, double-blind, placebo-controlled, phase II study (SOLAR) of high-dose vitamin D3 (vigantol oil, 14,000 IU/d) add-on to interferon $\beta-1 \mathrm{a}, 44 \mu \mathrm{g}$ subcutaneously 3 times weekly (Rebif), for 96 weeks in 348 RRMS patients, is currently under way. ${ }^{6}$

The SOLAR study group also includes Reinhold Vieth (SC member), Lizette Ghazi (SC member), Klemens Angstwurm, Simone Cursiefen, Ana Martins de Silva, Jan-Markus Dörr, Irina Elovaara, Juha-Pekka Erälinna, Markus Färkkilä, Masoud Falah, Jette Frederiksen, Steven Frequin, Claudio Gobbi, Bernd Griewing, Katrin Gross-Paju, Elisabeth Gulowsen Celius, Christina Käding, Claudia Kaiser, Jolanta Kalnina, Christian Kamm, Margitta Kampman, Keijo Koivisto, Samuel Komoly, Christian Lampl, Dalia Mickeviciene, Kjell-Morten Myhr, Lina Malciene, Michael Linnebank, Martin Marziniak, Said Masri, Stefanie Müller, Rui Pedrosa, Dieter Pöhlau, Nils Richter, Thorsten Rosenkranz, Csilla Rozsa, Ma José Sá, Vasco Salgado, Johnny Samijn, Evert Sanders, Taneli Sarasoja, Okke Sinnige, Bjarne Sivertsen, Merja Soilu-Hänninen, Martin Stangel, Egon Stenager, Oliver Stich, Florian Stögbauer, Toomas Toomsoo, Sabine Urbanits, Lászlo Vécsei, Freek Verheul, and Uwe K. Zettl.

Copyright () 2012 by AAN Enterprises, Inc.

1. Stein MS, Liu Y, Gray OM, et al. A randomized trial of high-dose vitamin D2 in relapsing-remitting multiple sclerosis. Neurology 2011;77:1611-1618.

2. Lucas RM, Ponsonby AL, Dear K, et al. Sun exposure and vitamin $\mathrm{D}$ are independent risk factors for CNS demyelination. Neurology 2011;76:540-548.

3. Nield LS, Mahajan P, Joshi A, Kamat D. Rickets: not a disease of the past. Am Fam Physician 2006;74:619-626.

4. Sormani M, Miller D, Comi G, et al. Clinical trials of multiple sclerosis monitored with enhanced MRI: new sample size calculation based on large data sets. J Neurol Neurosurg Psychiatry 2001;70:494-499.

5. Hiremath GS, Cettomai D, Baynes M, et al. Vitamin D status and effect of low-dose cholecalciferol and high-dose ergocalciferol supplementation in multiple sclerosis. Mult Scler 2009;15:735-740.

6. Smolders J, Hupperts R, Barkhof F, et al. Efficacy of vitamin $\mathrm{D}(3)$ as add-on therapy in patients with relapsing-remitting multiple sclerosis receiving subcutaneous interferon beta- $1 \mathrm{a}$ : a phase II, multicenter, double -blind, randomized, placebocontrolled trial. J Neurol Sci 2011;311:44-49. 